Meta

Journal des traducteurs

Translators' Journal

\title{
Television News Translation in the Era of Market-driven Journalism
}

\section{Claire Tsai}

Volume 57, numéro 4, décembre 2012

Journalisme et traduction

Journalism and Translation

URI : https://id.erudit.org/iderudit/1021233ar

DOI : https://doi.org/10.7202/1021233ar

Aller au sommaire du numéro

Éditeur(s)

Les Presses de l’Université de Montréal

ISSN

0026-0452 (imprimé)

1492-1421 (numérique)

Découvrir la revue

Citer cet article

Tsai, C. (2012). Television News Translation in the Era of Market-driven Journalism. Meta, 57(4), 1060-1080. https://doi.org/10.7202/1021233ar
Résumé de l'article

Les experts en traduction font remarquer que le rôle des traducteurs dans la transmission des informations internationales est en évolution constante et ils incitent ces traducteurs spécialisés dans l'information à s'adapter efficacement à ces nouveaux changements. On n'évoquait guère dans le passé le journalisme de marché, phénomène de plus en plus répandu, ni son influence sur la traduction de l'information qu'il produit. Les chaînes de télévision, esclaves du taux d'écoute, révisent leur position et éditent leurs informations en continu pour donner la primauté aux informations susceptibles d'attirer le plus grand nombre de téléspectateurs. Les traducteurs se voient ainsi dans un rôle très similaire à celui du journaliste. L'apparition et le développement d'un journalisme orienté vers le marché permettent aux experts d'étudier comment ces changements qualitatifs du journalisme font évoluer les stratégies de traduction de ces traducteurs spécialisés dans le journalisme. Cette nouvelle tendance nous offre aussi un regard sur la perception que le monde académique se faisait antérieurement des qualités intrinsèques d'une traduction. Nous avons récolté et analysé les informations télévisées produites par une chaîne commerciale taïwanaise et tenté de dessiner les grandes lignes de ce nouveau rôle joué par les traducteurs d'un journalisme totalement tributaire du marché.
Ce document est protégé par la loi sur le droit d'auteur. L'utilisation des services d'Érudit (y compris la reproduction) est assujettie à sa politique d'utilisation que vous pouvez consulter en ligne.

https://apropos.erudit.org/fr/usagers/politique-dutilisation/ 


\title{
Television News Translation in the Era of Market-driven Journalism
}

\author{
CLAIRE TSAI \\ National Taipei University of Technology, Taipei, Taiwan \\ ctsai@ntut.edu.tw
}

\begin{abstract}
RÉSUMÉ
Les experts en traduction font remarquer que le rôle des traducteurs dans la transmission des informations internationales est en évolution constante et ils incitent ces traducteurs spécialisés dans l'information à s'adapter efficacement à ces nouveaux changements. On n'évoquait guère dans le passé le journalisme de marché, phénomène de plus en plus répandu, ni son influence sur la traduction de l'information qu'il produit. Les chaînes de télévision, esclaves du taux d'écoute, révisent leur position et éditent leurs informations en continu pour donner la primauté aux informations susceptibles d'attirer le plus grand nombre de téléspectateurs. Les traducteurs se voient ainsi dans un rôle très similaire à celui du journaliste. L'apparition et le développement d'un journalisme orienté vers le marché permettent aux experts d'étudier comment ces changements qualitatifs du journalisme font évoluer les stratégies de traduction de ces traducteurs spécialisés dans le journalisme. Cette nouvelle tendance nous offre aussi un regard sur la perception que le monde académique se faisait antérieurement des qualités intrinsèques d'une traduction. Nous avons récolté et analysé les informations télévisées produites par une chaîne commerciale taïwanaise et tenté de dessiner les grandes lignes de ce nouveau rôle joué par les traducteurs d'un journalisme totalement tributaire du marché.
\end{abstract}

\section{ABSTRACT}

Translation scholars have discussed the changing role of translation in the transmission of international news information and called for news translators to adapt to such changes. However, the previous discussion has neglected to address the emerging phenomenon of market-driven journalism and its implications for news translation. Ratingsconscious news stations are beginning to revise news agendas and editorial priorities with a view of competing for audiences. Translators who work in newsrooms also assume a role that is traditionally associated with journalists. The rise of market-driven journalism affords scholars the opportunity to consider how the changing ethos of journalism alters news translation strategies. Furthermore, this change forces a rethinking of some earlier assumptions regarding the nature of translation. Although the prevailing trend of marketdriven journalism crosses over different media types, this paper primarily centers on the case of television journalism. By examining authentic broadcast news items that were collected from a commercial television news station in Taiwan and interviews with senior TV news translators, this paper unveils a new profile of television news translators in a news ecology that is defined by market values.

\section{MOTS-CLÉS/KEYWORDS}

actualités télévisées, journalisme de marché, sensationalisme, tabloïdisation, infodivertissement

television news, market-driven journalism, sensationalism, tabloidization, infotainment 


\section{Introduction}

In Taiwan, if one claims to work at a TV news station, then people immediately tend to assume that such a person works as a news presenter or a journalist. These two labels are the most common images attached to TV newsrooms in a country of 23 million people with seven 24/7 all-news cable channels and five terrestrial channels, including one public television channel. Although international news is an indispensable and integral part of daily newscasts, this type of news constitutes a relatively small proportion of all news and is easily replaceable when there is a major domestic news break. Recent research on international news also views such neglect as a global trend (Paterson and Sreberny 2004). The global journalistic landscape is changing both in the proportion of international news reporting and in the style and format of news presentation. The influence of the rapidly developing market-driven journalism and its most prominent features, which generally include sensationalism, tabloidization and infotainment, is gaining momentum around the globe.

Changing program forms, channel proliferation and the rise of the internet have exerted considerable pressure on television stations to increase ratings. According to Thussu, news and current affairs are usually not profitable (Thussu 1998: 68). News channels tend to "dilute the news content and make it more like entertainment" (Thussu 1998: 70) to become more profitable. According to Thussu and Freedman, 24/7 rolling news has become "a television genre in its own right" (Thussu and Freedman 2003: 117). Except for one public service station, all ten media outlets in Taiwan are highly commercialized. Apart from these eleven channels, there are 124 cable and satellite channels broadcasting various programs on a daily basis. Taiwan has a fiercely competitive television market. The advent of live 24/7 news is accompanied by the rise of market-driven news agendas and editorial priorities in which news presentation is as important as the content of reports. The role and responsibilities of news translators is changing, but such changes have not been adequately examined in recent scholarly inquiry (see for example Chen 2011; Lee 2006; Li 2006). Even when news translators are mentioned in discussions of journalism, they are generally assumed to play a "subterranean" role (Zelizer 2009: 5) in news production. Moreover, recent research on news translation in translation studies has primarily been concerned with the more well-researched field of print media translation (see for example Chen 2011; Bielsa and Bassnett 2009; Bielsa 2007); in contrast, television news translation has been inadequately explored. This paper seeks to investigate this less studied area and describe how the changing face of journalism shapes the manner in which broadcast news is produced and translated.

This paper is an ethnographic production that reflects on my six years of newsroom experience and on the experience of my former colleagues based on the interviews that I conducted with these individuals. The major data provider of this study is Formosa Television (FTV), a commercial station in Taiwan that provides original programming through one multi-genre network that operates in the terrestrial channel and one 24/7 cable news network. I embarked upon a field study at FTV International News Center in Taiwan during two weeks from August 28, 2007 to September 10, 2007. I interviewed five senior TV news translators, including the chief news coordinator, who have an average of more than 10 years of newsroom experience. ${ }^{1}$ These interviewees were asked whether the prevailing market-driven journal- 
ism in Taiwan has changed the manner in which they translate international news and, if so, how this trend has changed their practices. Given the excessive number of practical considerations in TV newsrooms, it is nearly impossible to collect the entire source corpus of one single news item that would be adequate for the purpose of close analysis if the researcher is not present in the newsroom to witness the production process or is unable to interview the news translators. This accessibility aspect of research in TV newsrooms distinguishes empirical research on TV news translation from research on other modes of translation.

There are instances in which TV news translation involves multiple and hybrid sources that are transmitted by news agencies and network broadcasters, and source texts are sometimes sufficiently blurred to prevent identification (see Tsai 2010). In addition, most subscribed, recorded verbal and visual material is erased approximately a week after it is first received at a news station, and the accessibility and complexity of material that is found from alternative sources, such as the Internet, creates even more difficulties for researchers. Only finished, already broadcast news items are stored in the newsroom archives for later retrieval. Bell provides an extensive discussion of the difficulties of conducting empirical research inside of a media house (see Bell 1991: 9-32).

This paper illustrates authentic examples that were either retrieved from my prior insider observation as a news translator or collected between 2004 and 2007 at different stages of the following discussion in addition to a detailed case study using Ekström's three modes of communication as an analytical model (Ekström 2000). Outsider researchers who are not directly involved in the work of TV news translation frequently fail to observe the specific problems of the profession and tend to treat TV news translation as merely another form of translation or even a "borderline case of translation" (Tymoczko 2007: 66). However, insider researchers who are familiar with the procedures of the professional practice must guard against their tendency to claim that they know everything that they need to know. Winter suggests that practitioners enter the field of investigation with a flexible mindset to gain new insights:

Experienced practitioners approach their work with a vast and complex array of concepts, theoretical models, provisional explanations, typical scenarios, anticipation of likely outcomes, etc.... A "research" process must demonstrably offer something over and above this pre-existing level of understanding. (Winter 1989: 34)

This paper records a personal journey from print and electronic media to academic research and thus combines the two strands of practice and theory. The perspectives from an outside translation theorist may diverge from those given by journalism theorists and practitioners, but this paper aims to challenge the differences and bridge this gap by examining the issues from multiple perspectives.

\section{Market-driven journalism and translation}

TV news translation has been a general practice in the production of international news since TV news broadcasting was first launched in Taiwan in 1962. Due to a limited budget for hiring overseas correspondents, international TV news production in Taiwan largely relies on global (TV) news agencies and network broadcasters. The 
job of a TV news translator is to process the basic stories that are supplied by these sources and "repackage" them for broadcasting in Mandarin Chinese. Translation is regarded as an integral part of the entire broadcast newsmaking process. As commercial television channels compete for the attention of viewers, new approaches with regard to news selection and different styles of news presentation are employed to appeal to audiences. This section examines the orientation toward market-driven journalism before discussing the nature of TV news translation and the manner in which this activity is influenced by the market-driven trend.

\subsection{Market-driven journalism}

The concept of market-driven journalism became prevalent during the late 1960s (see Hallin 1992). For many decades, the trend has continued to develop and has undergone various phases of transformation. In a study of the rise of market journalism, McManus views TV viewers as consumers, news as a product and the news circulation area as a "market" (McManus 1994: 1). He illustrates four markets that journalism serves: the market for audiences, the market for investors, the market for advertisers and the market for news sources. In his view, commercial news stations are more likely to serve these markets (McManus 1994: 5). The trend of market-driven journalism has been prevailing in Taiwan. In commercialized and highly competitive media production, newsmakers favor soft news over hard news. Traditional news values and the role of the media are being challenged. Many local researchers have been alerted to the phenomenon (Wang, Chow et al. 2010; Lin 2009; Wang 2004; Wang and Cohen 2009).

One of the most prominent characteristics of market-driven journalism is the orientation of news-making toward tabloidization and sensationalism. According to the chief news coordinator at FTV International News Center (2007), ${ }^{2}$ news values are increasingly defined by three key factors (i.e. drama, entertainment and personalities) as a result of market-driven journalism. The nature of news as an informative genre interacts with "the commodification of news and the pursuit of viewer ratings" (Harrison 2006: 68). Harrison emphasizes that news organizations have a wide range of aims, including making a profit and prioritizing public interest. News presentation and news content are adjusted due to the increased competition for audiences. In her words, "news is selected, produced and presented within the context of a particular news ecology within which it is located" (Harrison 2006: 128). A news ecology that is marked by the entertainment element is the basis for further discussion.

When Paris Hilton was released from jail on June 26, 2007, Mika Brzezinski, anchorwoman of a MSNBC morning news program, refused to read a script about the American socialite, tore up the scripts on air, called the report "an awful story" and turned back toward the camera to say "To the news now." The episode entered the news chain through YouTube and was taken and transmitted by many news agencies and network broadcasters. The episode was also taken by FTV and included in the newscast of the day. Whether the "Paris released from jail" item merits any media attention prompts us to consider a constant area of interest with regard to journalistic news values. The "Paris released from jail" item did not disappear from the screen, because of the outspoken, on-air protest of one or two newsworkers. Nevertheless, the news item received wide coverage. Even more interestingly, the 
Mika Brzezinski piece that originally aimed to degrade the tabloid news became yet another juicy piece of tabloid news itself. This occurrence appears to reflect an ironic reality that the popularity of infotainment has not abated despite the continuous criticism that it has received (Sparks 2000; Thussu 1998; Franklin 1997). Franklin (1997) voices his concern regarding this prevailing trend, which he believes crosses over different media types, including both print and broadcast media. He thinks that contemporary journalism has retreated from the reporting of hard news to the preferred territory of softer or lighter stories and that infotainment is "rampant" (Franklin 1997: 4).

In recent years, TV news has become less informative and more entertaining (Cohen 2002: 172) and has been aptly coined "infotainment." According to Thussu and Freedman, the term first emerged during the late 1980s to symbolize a mixed genre of "information" and "entertainment" in news and current affairs programs (Thussu and Freedman 2003: 122). In the broad sense of the term, the concept of infotainment is sometimes interchangeable with tabloid news and sensationalism. However, tabloids are characterized by a lighter approach and the dramatization of news and primarily cover gossip and scandals, whereas sensationalism is the key element of media content that attracts attention and excites or inflames emotions (McQuail 2005: 567). There have been debates for and against tabloid media that revolve around the production, distribution and reception of media messages. According to the thesis of Sparks, tabloid journalism covers issues that more directly concern the public compared with the issues covered by serious journalism (Sparks 2000: 27).

Thussu further emphasizes that the focus on making news "fun" to watch is substantiated by audience attitudes toward news (Thussu 1998: 72). According to an empirical study of television news audiences in Taiwan (Wang 2004: 94), TV news stories that are produced with sensational features and narrated in dramatic storytelling modes may result in stronger audience emotional arousal and more positive evaluations. Sensational production features also enhance audience attention and recognition of the news. This finding echoes that which was emphasized by the Chief news coordinator (2007; see note 2): television news does not merely involve delivering facts; rather, journalists must ensure that broadcast stories are of poignant interest to the audience.

Taiwan's television news station relies heavily on source material that is furnished by (video) news agencies and global network broadcasters; therefore, when international news stories enter Taiwan's media outlets, the choice of topics, content and news angles is confined to a predetermined agenda. If a news story that is supplied by $\mathrm{CNN}$ is entertaining in nature, then the translated version of such a story for final broadcast in Taiwan is unlikely to become less entertaining. The pursuit of ratings by media outlets has prompted TV news translators to update their skills and strategies as well as to find and devise presentation styles that are more likely to attract audience attention.

Empirical evidence at FTV reveals that sensational soft news and spot news with extraordinary footage are always given higher priority in news selection. Of the 211 international news items that aired between September 3, 2007, and September 9, 2007, 122 items were soft news and thus constituted more than half of the total items broadcast. Of the 89 hard news items, 39 items were political news, whereas the other 
50 items were categorized as spot news, including accidents, disasters, murder, crimes and other common threads in these types of stories. As a whole, more than $80 \%$ of the week's international newscasts were inundated with soft news and spot news, including such items as Woman Ate 173 Spicy Chicken Wings in 12 Minutes, Crocodile Invasion of Private House, Birthday Party for a Female Panda, Brad Pitt and Wife at the Venice Film Festival, Ear Spa in Japan, and 90-Year-Old Lady Becomes University Freshman.

The next section looks at Mats Ekström's three analytically distinct modes of communication which are illustrative of the nature and characteristics of broadcast journalism. Although Ekström's framework concentrates primarily on the production and presentation of news and current affairs programs, its concepts apply to TV news translation.

\subsection{Mats Ekström's three modes of communication}

Similar to any frame that delineates a world, news frames assume different sizes, shapes and textures. If news is "a window to the world," as Tuchman (1978: 217) has claimed, then television news is a moving glass mosaic window that is rich in color and dynamics and that opens the eyes of viewers to a kaleidoscope of information, stories and excitements through verbal and audio-visual channels.

Mats Ekström (2000) proposes a conceptual framework for TV journalism that explains how news presentation is influenced by the three modes of communication: information, storytelling and attraction. Ekström argues that if journalism were evaluated purely as a project to deliver information and enlighten people, it would hardly have been as successful commercially as it is today (Ekström 2000: 466). Instead of following the conventional dichotomy between information and entertainment or information and storytelling in analysis of journalism and media, Ekström presents a conceptual framework for TV journalism, in which three modes of communication are involved: information, storytelling and what he terms attraction with three corresponding metaphors of bulletin board, the bedtime story and circus performance.

On the one hand, Ekström proposes that different modes of communication are considered in terms of their communicative intentions in the journalistic production process involving a range of routinised choices and priorities (Ekström 2000: 466470). On the other hand, he takes into account the aspect of audience involvement and gratification to see how they relate to the three modes of communication. In the information mode of communication, journalists serve as informants whose primary function is to deliver information to audiences who crave for knowledge, whereas in the storytelling mode, journalists are storytellers who aim to satisfy their listeners' "lust for adventure, the pleasure of hearing a story, and the propensity to emphasize, to experience suspense and drama" (Ekström 2000: 468). When playing the role of an arranger and exhibitor, journalists strive for audience satisfaction to make an impression by presenting something spectacular and unusual through both audio and visual channels. Storytelling and attractions are two modes of communication which utilize the communicative power of visual images and dramatic elements. While the information mode of communication tends to be considered as more serious journalism, storytelling and attractions are more oriented towards news infotainment, tabloidization and sensationalism. 
According to Ekström, that which distinguishes the communicative strategies that are associated with the journalism of storytelling and attractions from the journalism of information is the former's greater emphasis on form than on content. Ekström's explains that "watching television is like going to the circus, watching something that takes place in an extraordinary situation, "in another world"” (Ekström 2000: 479). This is particularly relevant in the presentation of international news on TV in rating-driven markets such as Taiwan. Not all audiences turn on TV to remain informed and abreast of public affairs. Many viewers watch TV for reasons that are associated with "escapism, relaxation, leisure and amusement" (Ekström 2000: 479).

\subsection{Translating for the eyes and ears: The changing profile}

The trend of market-driven journalism is salient in both the selection and presentation of news, particularly in the visual mode of presentation. In the case of broadcast journalism, TV news translators are translating for the eyes and ears. The involvement of both verbal and visual codes in the process of translation gives translators greater discretion for manipulation. As broadcast news copy is written for the purpose of being spoken and written based on pictures, the interaction between narration and visuals in TV news translation becomes an important issue in the discussion of market-driven journalism.

As Gunter proposes, when visual illustrations, including moving pictures, stills or graphics, are used, the narration must relate to and support the visual elements in some manner (Gunter 1987: 171). Given the priority of television in film, narration should be crafted based on visuals to achieve a degree of analogy. With its complex production formats and participation frameworks (Fairclough 1995: 39), television is distinguished from radio and newspapers. Senior TV news translator D vividly describes this distinction as follows:

In television, the moving pictures tell the story, whereas narration plays a compensatory role; in radio, voices and narration are tools that make pictures emerge in the minds of listeners; and in newspapers, it is through the written words that readers construct the mental picture of the story. (Senior TV news translator D 2007) ${ }^{3}$

Brooks, Pinson et al. (2005: 369) suggest that "television news editing is the marriage of words to pictures, word to sound, picture to sound and ideas to ideas." In their words, "newspapers communicate with printed words, radio with spoken words and television with spoken words and moving pictures." Broadcast media differ from print media in that the former relies heavily on news feeds to tell a story, whereas the latter conveys messages only through written words. The representation of news coverage determines how a story will be received, and news with images can create a much stronger and lasting effect on an audience due to its ability to generate an emotional reaction to instant news (Schlesinger 1992: 127).

Based on experimental studies (Graber 1990; Gunter 1987), news that is accompanied by moving pictures reinforces an audience's memory of a news story. In most instances, audiences tend to turn on their TVs immediately after they hear breaking news on the radio or read about interesting issues in the paper to obtain a sense of feeling closer to the scene. According to Fairclough, images are presented to the audience "not in the frozen modality of newspaper photographs, but in movement 
and action" (Fairclough 1995: 38-39). Movement and action define actuality and "a medium through which reality can be genuinely and authentically captured and presented" in a manner that is optimally suited to the medium (Schlesinger 1992: 128). Gunter reiterates this notion as follows:

In a television newscast, the information which is predominant is generally that presented verbally via the auditory channel. Television news, however, is a multichannel medium of communication which offers considerable visual stimulation, and the audiovisual component of a televised information broadcast always occur within a visual context of some kind. (Gunter 1987: 127)

The visual mode of presentation has priority in television news production. When no footage is available, a news worker can either resort to the newsroom archive to locate similar films or create graphic illustrations or even animation to reinforce particular parts of a news story and facilitate the comprehension of the audience. The increasing emphasis on the presentation of the visual element on TV is the result of technology and competition. In the case of television news translation, stories with the potential for captivating pictures and/or sound have a much greater likelihood of being selected than stories that lack both entertaining pictures and sound. When encountering important but dull stories without attractive visual and audio, TV news translators can either resort to their imaginations through the use of computer graphics to create "extended metaphors" (Harcup 2004: 142) or simply seek archival footage for related feeds.

On September 7, 2007, Associated Press Television News furnished a story pertaining to four paintings by Monet and Alfred Sisley that were stolen from the Museum of Fine Arts in Nice, France, with a bland written description. The footage merely contained several shots of the interior and exterior of the museum that were interspersed with two otherwise dull sound bites by the curator. Such an item did not initially appear engaging and was nearly rejected by the assigner, but the news translator was sufficiently creative to search the archival footage and return with movie clips from the film Entrapment, in which Sean Connery played the world's greatest art thief. The news translator developed the story by adding the film clips at the beginning of the story in the form of nature sounds that merged with her narration: "In movies, the world's greatest art thief fancied the most expensive targets. In the real world, art theft actually happened in southern France" (my own translation). Tabloid style news packaging devices, according to Graber (1994: 497), "serve journalistic ideals by enhancing viewer attention to and interest in unarousing news content." In August and December 2007, Forbes magazine announced its latest survey on the top 100 movers and shakers in the political and business arenas, respectively. The news wires obtained the story and provided only written scripts. The TV news translator had to utilize many archival pictures of the named individuals, superimpose text on pictures and simultaneously present two visual scenes to illustrate contrast and reinforce audience memory. TV news translators not only translate but also carry out tasks generally associated with what journalists do. The advent of market-driven journalism allows larger space for manipulation and intervention in the production of news reports. The role of TV news translators is moving closer to that of journalists. It is argued that previous research in the field of news translation has reflected a disconnect between the way people on the job and academics view TV news translation. 
Some translation researchers (Gambier 2003; 2006; Gambier and Gottlieb 2001) strongly emphasize the significance of the visual code as a point of departure from earlier discussions of written translation, which involve only the verbal code. Although extremely useful in enabling us to understand the interplay among various codes, these studies did not adequately focus on the pluralistic and hybrid nature of the verbal and the visual sources that are connected with TV news production. The fundamental difference is that the footage that is used for TV news translation can be derived from multiple sources (e.g., raw TV news agency pictures, pre-fabricated network broadcaster pictures, archive footage or graphic illustrations and animation) and edited at the discretion of the news translator to accommodate the verbal code and vice versa.

There are instances in which a news translator writes a story that is built on various verbal-only source texts. As soon as s/he finishes writing the news item, s/ he must search for matching footage. The finished written item is then transformed from a target text to a source text, on the basis of which the footage is selected. After the verbal text is read as a voice-over and edited with the selected picture, the text becomes another target text that is recorded on a tape ready for broadcast. Hence, it can be confusing to view TV news translation based on the binary opposition of source and target text, which is a basic premise of translation. The dichotomy is even more blurred in this context, in which principally any material can become a source text, and a broadcast item need not be a rewrite or a translation of any source. The final recorded news item is a new text that is written based on some source texts that are loosely termed "rough notes" by TV news translators.

As Harcup notes, "some stories are entertaining by virtue of their subject matter. Others can be rendered entertaining by being well written, by holding the attention of the audience, by the use of anecdotes or asides, or by injecting humour" (Harcup 2004: 86). On the other end of the spectrum of news selection, the item that involved former US President George W. Bush on September 4, 2007, on his arrival at the APEC summit and his meetings with world leaders to discuss major economic and security issues was typical hard political news, in which, according to Bell (1991: 14), "a distinctive news style will be found if anywhere," and the interpretation of the story and the addition of personal comments are reduced to the minimum. However, the former president's verbal miscues during his APEC address three days later can be termed "soft news disguised as hard news" when he referred to the APEC gathering as the OPEC summit and Australia as Austria. During the daily newscast at FTV, one item was dedicated to Bush's APEC/OPEC error, in addition to many of his prior embarrassing moments in sound-bite forms. Senior TV news translator A explains as follows:

It is increasingly common for network broadcasters and news agencies to produce 'semi-hard news' - a mixture of hard news and some humorous bits. The dramatization of news is further intensified in the hands of the news translator to cater to the news market in Taiwan - another manifestation of the prevalent journalistic practice of supplying infotainment to the audience. (Senior TV news translator A 2007) ${ }^{4}$

The CNN journalist began the story as follows: "When you or I have a bad day, most people don't notice. But when the president of the United States has a bad day, the whole world sees." Indeed, the whole world observes with great enthusiasm, 
and to some extent, this example confirms the claim of Bird (2000: 223) that TV news audiences generally favor lively, dramatic human interest stories over political and economic news. Debates on various perspectives for and against tabloid media are beyond the scope of this paper. The neglect of the changing role of news translation in the current of infotainment is intriguing because news translators determine how international news is re-shaped and re-presented in a news market such as Taiwan.

On May 7, 2007, Nicholas Sarkozy emerged as the winner of the presidential election in France. The news translator at FTV produced a comprehensive news item detailing the election, the political effect and reactions from voters based on multiple wire scripts and network reports. At the key editorial meeting of the day, the senior TV news translator who assigned the translation was questioned for failing to select reports on Sarkozy's then wife, Cécilia Ciganer-Albéniz, and her alleged affair, as their competitor stations had chosen to do. Sarkozy has been a newsmaker since he took office. Such items fell under the "continuing news" category that culminated in his divorce in October 2007, which merited a large media report at FTV. The news translator produced a major story in addition to a complementary second report on his prior affairs with various women. In Taiwan's commercial television stations, hard international political news items are typically not particularly attractive to copy editors unless some juicy elements are incorporated to add hype to the events. The idea of market journalism informs the editorial selection process. As the former section chief of the International News Center of FTV, I was once informed at an editorial meeting that the hot air balloon festival in Switzerland would be more highly valued in the marketplace than the war in Chechnya. TV news translators oscillate between what is eye-catching and what the audience needs to know about world affairs.

The contention of Thussu (1998: 71) that "covering celebrities, scandals and personalizing 'human interest' stories helps international networks to sell their reports across the globe" is substantiated in Taiwan's commercial TV newsroom. This obsession with ratings is also reflected in the writing style of news translation in which news content is diluted to render it more similar to entertainment.

In discussing the link between sensationalism and TV news translation, one must inquire as to who renders the news as sensational. There are two angles in answering this question: first, a foreign news story may already be sensational in nature when the news station receives it. A news translator either follows the same trajectory or enhances its volume and degree of sensationalism. When working with a series of feature reports by CNN correspondent Jeanne Moos, a TV news translator essentially follows her storylines and angles. Additions are rare because Moos' reports are frequently prefabricated and packaged in a distinctive fashion in which rapid-fire editing and special visual effects are employed. Deletions are more common because significant culture-specific elements are embedded in these stories, and they are generally too long to fit into Taiwan's newscasts. Given the quirky nature of Moos' reports, it seems redundant for a news translator to add more humor to render these stories even funnier or more sensationalized. The real issue that the TV news translator encounters here is the question of how to select two or three funny bits out of many aspects. As the senior TV news translators explained in their interviews, a news translator may detach him/herself from the original storyline by exploring new angles 
of sensationalism, but this option would be subject to the availability of related source material, including footage and the time that is allowed for research.

Second, a news story may initially be categorized as soft news with limited traces of sensationalism but becomes sensationalized due to manipulation on the part of a TV news translator. Although highly sensationalized news can arguably become flat and dry news in the process of translation, such an outcome is not common in TV newsrooms in Taiwan and is frequently regarded as "bad writing" as a result of missing the entire point of the story, as indicated by Senior TV news translator B (2007)

The treatment of news may vary according to cultural differences or journalistic practices, but Taiwanese conventions do not involve keeping the audience in suspense until the end of the story. However, the more interesting aspect involves the manner in which news is prioritized. With the proliferation of tabloid-like production practices, TV news translators at FTV are expected to follow the rule of the "Golden 7.5 Seconds," a term that FTV has borrowed from a local TV talk show as the basic rule for its newsworkers. The Chief news coordinator described the rule as follows:

If you fail to attract the audience's attention within the first 7.5 seconds of a story, then they would almost certainly switch channels. Compliance with this rule involves a large-scale reorganization of scripts and, most of all, the proper utilization of explosive and compelling natural sound and sound bites in the very beginning of a news story. (Chief news coordinator 2007; see note 2)

The first seven and a half seconds are not necessarily the most important part of a news story but are certainly the most eye-catching aspects. Senior TV news translator B (2007; see note 5) used the news pertaining to China's panda conservation as an example: "There is much more important information regarding China's panda conservation plan in the story, but if the footage shows one panda taking a nap and looking adorable, this shot is definitely going to be shown at the beginning followed by other important bits." Another example is the reunion of the nineteen freed South Korean hostages with their family on September 2, 2007, after a six-week kidnapping drama in Afghanistan. Rather than following the order of the original scripts and raw footage, the TV news translator used the natural sound of ex-hostages crying in the arms of their families and the sound bite of their joint apology to the people of South Korea to lead the story, followed by the latest developments and background of the incident. The report was apparently emotionally arousing. Grabe, Zhou et al. (2000: 582) connected this type of emotional and psychological arousal on television news with the concept of news sensationalism, which is commonly regarded as a key ingredient of tabloid reporting.

The next section further examines the manipulation by a TV news translator in the translation of a CNN report. Special references are made to highlight the influence of market-driven journalism on TV news translation.

\section{A case study: "Weathered reporters"}

Following the previous discussion of market-driven journalism and the changing profile of TV news translators, this section explores further how the source texts are processed into final broadcast news. By adopting Ekström's framework of the three modes of communication, this case study analyzes "Weathered reporters," a report by CNN correspondent Jeanne Moos. Moos has a unique manner of telling a story. 
Her reports frequently involve more embedded sound bites to parallel her voice-over and more culture-specific elements in addition to complex professional editing techniques, all of which increase the difficulty of altering the package in the process of news translation. Despite the comic and satirical nature of such stories and their appeal to the audience, working with Moos' reports requires extra time and energy, according to all five interviewed senior TV news translators. This hurricane piece, which was covered during the period in which Mexico and many Central and Southern American countries were battered by heavy storms in August 2007, offers a good example of how a text is transformed by a TV news translator. The audience in Taiwan is not unfamiliar with Moos' reports which have been translated into Chinese and broadcast on TV on a regular basis. The recurring inclusion of Moos' reports into the day's newscast reflects news stations' preference for foreign news of a lighter nature. This original CNN report and its Chinese broadcast version are constructed based on the storytelling and attractions modes of communication.

Although a single source text is not common in TV news translation, the hurricane report was processed based on only one source, which was the original Moos report that aired on $\mathrm{CNN}$. The only difference is that the transcript of the hurricane report (see Appendix) was not accompanied by the packaged report that aired on TV. The news translator could rely on only the taped report to write the story in Chinese. Note that a comparison between the source transcript (which arrived at a later time) and the final report must consider several factors, such as the evanescent nature of spoken discourses, the difference between writing a story with a written script in front of a news translator and without such a script, and the time factor. Seleskovitch and Lederer reiterate the relationship between the oral and the written below:

The transcript does not show the speaker's intonation, which is why a statement may appear incoherent in writing while it was quite clear to the listening audience... The reader must remember that the interpreter's real-life consumers do not read the interpretation: they listen to it. (Seleskovitch and Lederer 1995: 48-49)

Likewise, the TV audience does not read Moos' report, nor does the Taiwanese audience read the final version. Rather, this audience listens to the report. The Moos report of one minute and fifty-seven seconds was reduced to one minute and fifteen seconds with the first ten seconds and the final thirty-two seconds removed from the final Chinese version. This reduction does not mean that the remaining one minute and fifteen seconds is a reproduction of the remainder of the original report. Furthermore, among the eleven sound bites that Moos used, only five sound bites were selected for inclusion. As the story was a CNN broadcast, the lead read was performed by the $\mathrm{CNN}$ presenter and is transcribed as follows (see also the Appendix):

(1) Don Lemon: Well, you guys know because all three of us do it. It takes a special kind of journalist to head out into a monster storm, right, just so everybody can get to see it. Well, you could call them - or us - weathered reporters. Here's CNN's Jeanne Moos.

(Transcripts 22 August 2007) ${ }^{6}$

When the audience in Taiwan heard the lead in Chinese, it sounded quite different:

（2）每次強烈風暴來襲, 您都會在電視機前, 看到記者在現場賣命演出, 而就某方 面來說, 光是從記者狼狽的樣子, 就可以判斷風災有多嚴重。 
[Whenever a heavy storm hits, you'll see journalists doing all they can on TV to put on a performance. To some extent, you can tell how serious the disaster is by judging from how awkward and embarrassing the journalists look.]

(News FTV 22 August 2007; translated by the author) ${ }^{7}$

This lead likely cannot be precisely called a translation because the news translator actually wrote his own lead in this specific case and because the writing was not based on the original lead. It is less a macrostructure that stems from the report as a whole than the news translator's own interpretation. The translator was writing to the pictures and sound. Given that TV journalists commonly make such efforts in Taiwan when reporting news pertaining to typhoons, the news translator was attempting to relate the audience to the hurricane context in Mexico. Moos' original report had a clear storyline, but the news translator replaced her narration with his own version. Moos used rapid editing of films and narration. With this fast-paced and entertaining beginning in terms of both verbal and visual presentation, Moos attracted the attention of the audience. However, this narration and these sound bites (see 1.2. in Appendix) were deleted altogether in the Chinese report and replaced by the following voice-over by the TV news translator:

（3）颶風狄恩來襲, 美國各家新聞台, 為了搶風災的一手畫面, 紛紛前進墨西哥, 除 了自己上陣, 還請來當地遊客配合演出。

[When Hurricane Dean struck, many TV news stations in the U.S. sent their journalists to Mexico to cover the disaster firsthand. They also invited tourists to get involved and team up with them.]

(News FTV 22 August 2007; translated by the author; see note 7)

The source text mentioned that journalists sometimes work as a human billboard demonstrating the meaning of windy (see 1.4. in Appendix), but the TV news translator expanded that short phrase as follows:

（4）隨著風風登陸, 風勢增強, 好戲也上場, 觀眾躲在家裡看電視, 這時候, 連線記 者的工作, 就是在鏡頭前, 充當風速測試員。

[As the hurricane landed, the strength of the gusty winds became stronger. The show is on. The audience is staying at home watching TV coverage while the TV journalist acts as a wind speed tester in front of the camera.]

(News FTV 22 August 2007; translated by the author; see note 7)

Except for the human billboard phrase, the entire section (1.4. in Appendix) was deleted by the news translator. Before introducing a dramatic film segment of two journalists competing with the gales in a prior report on Hurricane Wilma, Moos continued her narration and inserted one sound bite (see 1.5. in Appendix). The following text is the news translator's version:

（5）不過, 和幾年前 $\mathrm{NBC}$ 新聞記者轉播威瑪風風的搏命演出相比, 以上連線, 只能 算是小兒科。

[However, these live reports are no big deal compared with the one on Hurricane Wilma covered by the NBC journalists, who were virtually risking their life for the story.]

(News FTV 22 August 2007; translated by the author; see note 7) 
This Chinese narration was followed by a ten-second engaging footage along with the sound bites of two men struggling in the gales (see 1.6. in Appendix).

In the final thirty-two seconds of the original report (see 1.7. in Appendix), Moos used one additional interesting example to demonstrate how another broadcast journalist was affected by severe weather during a live report. Subsequently, Moos cued a close-up shot of an iguana to illustrate the relationship between a hurricane and an animal and to dramatically related the iguana to a commercial clip of an insurance company with an iguana look-alike cartoon character saying "no one ends up looking foolish"; thus, this clip implies that insurance is advisable for weatherbeaten reporters. Despite the intriguing narration accompanied by vivid footage for thirty-two seconds, the news translator removed this entire portion and replaced it with the following to end the report:

（6）看清楚了嗎?一個人拿麥克風, 一個人抱大腿, 兩條壯漢合力, 竟然還是被風吹 倒, 這種連線效果, 絕對比任何言語播報, 更有說服力。

[Did you just see that? One guy held the microphone while the other held his legs. Teamwork of two strong guys, and it didn't work. The effect of this kind of live report is definitely much more convincing than any other types of verbal reporting.]

(News FTV 22 August 2007; translated by the author; see note 7)

As mentioned earlier, only five sound bites were chosen for inclusion in the Chinese version. The final sound bite, which was followed by However, these live reports are no big deal compared with the one on Hurricane Wilma covered by the $N B C$ journalists, who were virtually risking their life for the story, (see note 7) and preceded the ending paragraph above, illustrates how the two journalists struggled to fight the gales with their microphones in hand. This explains why the above narration begins with Did you just see that? The sound bites in this hurricane report were selectively removed. This choice of sound bites also accounts for the deletions and permutations of sound bites as observed in this cast. A person's initial words can be moved backward and inserted in a later episode in a story if the voice-over is accordingly tailored to cue the sound bite at the right time. The five sound bites were removed and incorporated into the news translator's own storyline to develop a new meaning and a new angle. As Ekström indicates, "dramatized reconstructions of events represent a communicative strategy which constitutes the elementary form of journalism as storytelling" (Ekström 2000: 474). The TV news translator in this example resorted to the storytelling mode of communication with a view to establishing an intimate dialogue with the audience and generating higher viewership. In Ekström view, the storytelling mode of communication is one of the prime selling points in television production in general and not least in TV journalism (Ekström 2000: 472).

Moos' report itself is indeed humorous. Rather than following the conventional schematic and thematic structure of news discourse, the discourse of this piece is sometimes erratic. Interestingly, the erratic and imaginative construction of the news story distinguishes the story from other news reports. It would indeed be possible for the news translator to "reproduce" the entire story in another language for a different audience, but the news translator does not appear to have pursued such a goal. Drastic changes were made throughout the text. Deletions operated on the basis that the original report was excessively long for broadcast news in Taiwan. The numerous 
examples that Moos used to describe the similar context simply did not fit into a standard one minute and fifteen second item. These examples were removed not because of their lack of news value or a failure to meet the audience's demand; rather, these examples were removed because they did not suit news production routines in Taiwan. This explanation calls to mind the suggestion of van Dijk (1988) that transformations of source texts are governed by both event and situation models as well as constraints of newsmaking routines, content and structure.

Other reasons for deletion involve the news translator's personal preference for a particular news angle. For instance, consider the final part of the original report. The news translator had thought that the link to an insurance company was not particularly necessary and chose to end his report by placing more emphasis on the final dramatic sound bite and its accompanying pictures and by adding his personal comments: The effect of this type of live report is definitely much more convincing than any other types of verbal reporting. (see note 7)

According to van Dijk (1988: 117), textual additions require the insertion of relevant details from other sources or from a journalist's prior models and general knowledge to function as explanatory and embedded. In this hurricane example, however, the addition did not operate in an explanatory manner; rather, the addition was intended to assist in presenting the story in the news translator's distinctive style. Nevertheless, the permutations in this example were more salient only in the sequence of sound bites rather than in the narration, which involved extensive rewriting by the news translator. The news translator may have moved the final sound bite to the top of the story to promise a dramatic and picture-arresting beginning and to conform to the "Golden 7.5-Second" rule. There are a variety of options for transformations in the process of TV news translation, but Senior TV news translator D provides the following reminder:

Excessive manipulation of Moos' report may risk ruining a well-organized and welledited package and cause her originality to disappear altogether. Nevertheless, if the news translator is able to give new life to the source report by constructing a different yet convincing and even more interesting narration, the above worries become gratuitous because in TV news translation, the originality of the source text can be compensated and compromised. (Senior TV news translator D 2007; see note 3)

In this hurricane example, the story ended in a different manner, but the effect of drama was still present. In this report, there appear to be more traces of originality from the TV news translator than from Jeanne Moos herself. In most instances, the TV news translator clearly preferred to use the pictures rather than Moos' narration for his story. The footage occupied a central position in the production process. This echoes Ekström's attraction mode of communication that broadcast newsmakers focus on finding stories and images that may be expected to have a shocking, fascinating and striking potential (Ekström 2000: 478).

\section{Conclusion}

Journalists produce and deliver news to a maximum number of viewers by communicating through the informative, storytelling and attraction modes of communication. In the past, news translation was performed primarily on the basis of traditional news values that were less constrained by such commercial factors as ratings. The 
change in criteria to qualify an international event as news has led to significant changes in how news translation is performed. The surrender of TV news translators to market factors in news selection and news presentation reflects an ambivalent sense of identity among TV news translators regarding what the profession actually involves and how they feel about this issue.

In her discussion about the changing faces of journalism, Zelizer (2009) notes the increasing multiplicity of journalism in the face of rapid changes of the journalistic landscape. The new tools of information relay and the new models of newsmaking have encouraged journalists to treat large issues in personal terms. The general presumption is that if the public simply reject the news out of boredom, they are not well informed (Zelizer 2009). In the end, it seems that whatever sells lead. Zelizer's sobering remarks imply the tendency of newsmaking toward market-driven journalism. TV news translation is not immune to the generally criticized "dumbing down" in broadcast newsmaking (Paterson and Sreberny 2004; Thussu 1998; 2004). Going in-depth may seem too much to ask for daily news on TV which is constantly constrained by space and time. The general lack of historical background on any given TV news items is attributed by MacGregor to a low degree of interest among the audience and the nature of daily television broadcast which is simply not set up to do the job (MacGregor 1997: 67). For TV news translators who cannot resist the temptation constantly to refine their translation in the production phase may find themselves sitting uncomfortably in the fast-paced broadcast newsroom where rapidfire writing and editing is commonplace and ratings are the norm. When the amount of news reaches a critical mass enough for all newscasts in the day and when competitor stations are all running similar newscasts, the question then becomes "how to be different," or, to be more precise, "how to be funnier."

On the basis of this study, several aspects which specifically characterize the changing profile of the TV news translator are observed. Television is a medium involving both verbal and visual codes. Information, story-telling and attraction constitute the three modes of communication typical in TV journalism. Apart from delivering information, TV news is frequently presented in the form of storytelling with a view to engaging audiences and ensuring viewer ratings. The high density of 24/7 rolling news networks in Taiwan may signify at first glance the prosperity of the electronic media, but a closer look at their newscasts reflects a high degree of homogeneity. With a view to distinguishing itself from competitor stations, TV news translation in Taiwan is increasingly tilting towards market-driven journalism. The status of the source text in TV news translation is different from what is perceived in the binary opposition between the source and the target text in translation. After being given an assignment, news translators cannot simply rely on the primary source material provided by global news agencies or network broadcasters. More often than not, they seek new sources from different news platforms, reuse prior reports and add new angles and comments to reinforce the attraction of a news item. They take facts and events out of one context and reshape them in appropriate formats into a new story. The processing of an infinite supply of raw material is at the same time complemented by large-scale film editing to ensure that the interaction between the visual and the verbal tracks is properly guided within time and space limitations.

Furthermore, TV news translation is significantly constrained by news values in terms of news story selection and news content selection. Conventional news values 
remain valid in my discussion of contemporary TV news making, including TV news translation. It is precisely based on these basic journalistic values that news translators determine what is integrated into a news item as newsworthiness and what is discarded out of a myriad of source texts. It is worth noting that the rise of infotainment and tabloid-style reporting has also informed the writing of news translators, leading to drastic transformations of the source texts, to cater to the linguistic and cultural prescriptions as well as the preference of the target audience. Such a notion of domestication goes far beyond what translation studies have so far explained. For if the domestication (as is often treated from the translational point of view) of TV news involves the invention of a new context and the rewriting of a completely new text, its legitimacy as a translation becomes questionable. Although translation is a form of rewriting, not all rewritings are translations. It is worthwhile noting that all five senior TV news translators interviewed in this study agree that TV news translation is something other than translation as we understood the term. In the era of market-driven journalism, the task of TV news translators is becoming more diversified, closer to what journalists do.

When researchers do talk about news translation, the subject of journalism which news translation evolves around generally takes up a peripheral role in their inquiry. It is equally important to take a look at how other disciplines like media and journalism studies talk about (news) translation and in what proportion. Academic research into international news production in either the field of mass communication or journalism rarely touches upon the issue of translation. As put by Vuorinen (1999: 163), "typically, in studies dealing with international mass communication, translation is either completely ignored or only mentioned in passing." The closest we get is discussion about domestication. Much has been said about the domestication of international news (see Wang 2004; 2010; Harrison 2006; Clausen 2003; Cohen 1996), but almost none of this relates the concept of domestication to translation studies and translation is mentioned rarely. In Harrison's words (2006: 127), journalism professionals generally mean "reporters, producers, technical staff and managerial staff." Clausen recognises "language as an issue in the 'domestication' of international news" (Clausen 2003: 134) and translation as an extra-media factor but gives different titles for those engaged in interlingual news writing, e.g. domesticators (Clausen 2003: 184) or scriptwriters ("who translate information from foreign agencies and rewrite it”) (Clausen 2003: 159).

The neglect and inadequacy of discussion of translation in journalism studies, media studies or media sociology as raised by Bielsa (2007: 152) may reside in the fact that news translators are generally regarded as or expected to be journalists. Research related to international news translation in the aforementioned disciplines tends to see limited significance in isolating translation from their disciplines and reject to look at news translation solely from a translational point of view. Those who view translation as a discipline broad enough to cover everything TV news translation has to say and neglect the pivotal role journalism plays may be missing the forest for the trees. By focusing on market-driven TV news translation, this paper has sought to illustrate the missing link and called for a more genuine and broader collaboration across disciplines. By establishing a harmonious and reciprocal, if not competing, relationship between translation and journalism, researchers in this field shall contribute to accumulation of knowledge and to a better world of information 
where international news is aptly shaped and disseminated through the skillful hands of TV news translators.

To be able to pour new wine into an old bottle may signify a new development in some academic research. In Translation Studies, there has been an unfailing supply of new wine derived from a diversity of research over the decades. What we need for TV news translation is a new bottle altogether.

\section{ACKNOWLEDGMENTS}

I would like to thank the two anonymous reviewers for their valuable and helpful suggestions on an earlier version of this paper.

\section{NOTES}

1. Interviewees in this study chose not to reveal their true names. They were thus represented by A, $\mathrm{B}, \mathrm{C}, \mathrm{D}$, or their title only.

2. Personal interview with Chief news coordinator at FTV International News Center, on 15 August 2007.

3. Personal interview with Senior TV news translator D, on 8 September 2007.

4. Personal interview with Senior TV news translator A, on 13 August 2007.

5. Personal interview with Senior TV news translator B, on 14 August 2007

6. TRANSCRIPTS (Transcripts Providers) (22 August 2007): U.S. Army Helicopter Crashes in Iraq; Hurricane Dean Weakens. CNN Newsroom. Visited on 30 September 2012, <http://www.studentnews.cnn.com/TRANSCRIPTS/0708/22/cnr.05.html $>$. The video (without the lead) can be found here: CNN (2007) 2007: Weathered Reporters. CNN videos, added on 26 August 2011. Visited on 30 September 2012, <http://www.cnn.com/video/\#/video/weather/2011/08/26/vault.moos.weather. reporters.cnn>.

7. NEWS FTV (22 August 2007): 颶風連線 記者搏命演出. Visited on 15 October 2007, <http://news. $\mathrm{ftv} . \mathrm{com} . \mathrm{tw} /$ NewsContent.aspx? $\mathrm{ntype}=$ class\&sno $=200782211 \mathrm{I0} 0 \mathrm{M1}>$.

\section{REFERENCES}

BeLL, Allen (1991): The Language of News Media. Oxford: Basil Blackwell.

BIELSA, Esperança (2007): Translation in global news agencies. Target. 19(1):135-155.

Bielsa, Esperança and BAssnett, Susan (2009): Translation in Global News. London/New York: Routledge.

BIRD, S. Elizabeth (2000): Audience demands in a murderous market: Tabloidization in U.S. television news. In: John Tulloch and Colin Sparks, eds. Tabloid Tales: Global Debates over Media Standards. Lanham: Rowman \& Littlefield, 213-228.

Brooks, Brian S., Pinson, James L. and Sissors, Jack Zanville (2005): The Art of Editing: In the Age of Convergence. Boston: Pearson/Allyn and Bacon.

Chen, Ya-mei (2011): The translator's subjectivity and its constraints in news transediting: A perspective of reception aesthetics. Meta. 56(1):119-144.

Clausen, Lisbeth (2003): Global News Production. Copenhagen: Copenhagen Business School.

Cohen, Akiba A. (1996): Global Newsrooms, Local Audiences: A Study of the Eurovision News Exchange. London: J. Libbey.

Cohen, Akiba A. (2002): Globalization Ltd.: Domestication at the boundaries of foreign television news. In: Joseph Man Chan and Bryce Telfer McInTy re, eds. In Search of Boundaries: Communication, Nation-States, and Cultural Identities. Westport/London: Ablex, 167-180.

ЕкsтRӧм, Mats (2000): Information, story-telling and attractions: TV journalism in three modes of communication. Media, Culture and Society. 22(4):465-492.

FAIrClough, Norman (1995): Media Discourse. London: Edward Arnold.

Franklin, Bob (1997): Newszak and News Media. London/New York: Arnold. 
Gambier, Yves (2003): Screen Transadaptation: Perception and Reception. The Translator. 9(2):171-189.

Gambier, Yves (2006): Transformations in International News. In: Kyle ConwaY and Susan Bassnett. Translation in Global News. (Proceedings of the conference held at the University of Warwick, Coventry, 23 June 2006). Coventry: University of Warwick, Centre for Translation and Comparative Cultural Studies, 9-22.

Gambier, Yves and Gottlieb, Henrik (2001): (Multi)media Translation: Concepts, Practices, and Research. Amsterdam/Philadelphia: John Benjamins.

Grabe, Maria Elizabeth, Zhou, Shuhua, Lang, Annie, et al. (2000): Packaging television news: The effects of tabloid on information processing and evaluative responses. Journal of Broadcasting \& Electronic Media. Fall:581-598.

Graber, Doris A. (1990): Seeing is remembering: How visuals contribute to learning from television news. Journal of Communication. 40:134-155.

Graber, Doris A. (1994): The infotainment quotient in routine television news: A director's perspective. Discourse \& Society. 5(4):483-508.

Gunter, Barrie (1987): Poor Reception: Misunderstanding and Forgetting Broadcast News. Hillsdale: Lawrence Erlbaum Associates.

Hallin, Daniel C. (1992): Sound bite news: Television coverage of elections, 1968-1988. Journal of Communication. 42(2):5-24.

Harcup, Tony (2004): Journalism: Principles and Practice. London: Sage Publications.

HARRISON, Jackie (2006): News. London/New York: Routledge.

LeE, Chang-soo (2006): Differences in News Translation between broadcasting and newspapers: A case study of korean-english translation. Meta. 51(2):317-327.

LI, Defeng (2006): Translators as well as thinkers: Teaching of journalistic translation in Hong Kong. Meta. 51(3):611-619.

Lin, Chao-chen (2009): What's wrong with ratings: a critical study on Taiwan ratings. Communication and Society. 8:109-134.

MacGregor, Brent (1997): Live, Direct, and Biased?: Making Television in the Satellite Age. London: Arnold.

McQuall, Denis (2005): McQuail's Mass Communication Theory. London: Sage Publications.

McManus, John H. (1994): Market-driven Journalism: Let the Citizen Beware? London: Sage Publications.

Paterson, Chris and Sreberny, Annabelle (2004): International News in the 21 $1^{\text {st }}$ Century. Eastleigh: John Libbey.

Schlesinger, Philip (1992): Putting 'Reality' Together: BBC News. London: Routledge.

Seleskovitch, Danica and Lederer, Marianne (1995): A systematic approach to teaching interpretation. (Translated by Jacolyn HARMER) Silver Spring: Registry of Interpreters for the Deaf.

Sparks, Colin (2000): The panic over tabloid news. In: John Tulloch and Colin Sparks, eds. Tabloid Tales: Global Debates over Media Standards. Lanham, Md.: Rowman \& Littlefield, $1-40$.

Thussu, Daya Kishan (1998): Infotainment international: A view from the south. In: Daya Kishan Thussu, ed. Electronic Empires: Global Media and Local Resistance. London/New York: Arnold, 63-82.

Thussu, Daya Kishan (2004): News as Entertainment: The Rise of Global Infotainment. London: Sage Publications.

Thussu, Daya Kishan and Freedman, Des (2003): War and the Media. London: Sage Publications.

TsAI, Claire (2010): News translator as reporter. In: Christina SCHÄFFner and Susan BAssnetT, eds. Political Discourse, Media and Translation. Newcastle upon Tyne: Cambridge Scholars Publishing, 178-197.

Tuchman, Gaye (1978). Making News: A Study in the Construction of Reality. New York: The Free Press. 
Tүмосzко, Maria (2007): Enlarging Translation, Empowering Translators. Manchester/Kinderhook: St. Jerome Publishing.

van Dijk, Teun Adrianus (1988): News as Discourse. Hillsdale/London: Lawrence Erlbaum Associates.

Vuorinen, Erkka (1999): Crossing cultural barriers in international news transmission: A translational approach. In: Jeroen VANDAELE, ed. Translation and the (Re)Location of Meaning, Selected Papers of the CETRA Research Seminars In Translation Studies 1994-1996. Leuven: CETRA Publications, 61-82.

WANG, Tai-li (2004): The impacts of sensationalism on audiences' receptions of television news. Mass Communication Research. 86:91-133.

Wang, Tai-li, Chow, Rebecca and Lo, Vei-Hwei (2010): Tabloidization in Taiwan's foreign television. The Chinese Journal of Communication and Society. 13:75-108.

Wang, Tai-li and Cohen, Akiba A. (2009): Factors affecting viewers perceptions of sensationalism in television news: A survey study in Taiwan. Issues \& Studies. 45(2):125-157.

Winter, Richard (1989): Learning From Experience: Principles and Practice in Action-Research. London: Falmer.

Zelizer, Barbie (2009): Why journalism's changing faces matter? In: Barbie Zelizer, ed. The Changing Faces of Journalism: Tabloidization, Technology and Truthiness. London/New York: Routledge, 1-10.

\section{APPENDIX}

Original CNN transcript of "Weathered reporters" by Jeanne Moos (see note 6)

1.1 .

Lead:

DON LEMON: Well, you guys know because all three of us do it. It takes a special kind of journalist to head out into a monster storm, right, just so everybody can get to see it. Well, you could call them - or us - weathered reporters. Here's CNN's Jeanne Moos.

1.2.

JEANNE MOOS, CNN CORRESPONDENT (voice-over): When there's a hurricane and they say...

UNIDENTIFIED FEMALE: Breaking news.

MOOS: ...prepare for breaking waves.

UNIDENTIFIED FEMALE: Apparently everyone that came in here with me...

MOOS: Did CBS's weatherman learn from that wave? Nah. Minutes later, a couple of honeymooners got wet.

UNIDENTIFIED MALE: The airports were full.

1.3.

MOOS: American honeymooners had it tough, as one bride's dad pointed out...

UNIDENTIFIED MALE: Notice Beth's mascara is running. I wish she would fix that.

MOOS: Mascara damage is not what most storm reporters fear.

1.4 .

UNIDENTIFIED MALE: OK, move it a little bit out of the way because we have some debris coming down the street here. Matt, I'm just going to step out of the way here, only because I'm getting sort of a sense of an unease here as some of this stuff is blowing around now.

MOOS: The bad news would be getting hit by debris. The good news is being a human billboard demonstrating the meaning of windy.

WHITBECK: The roar is like that of a jet engine.

MARCIANO: And that just pushes the water and me with the wind. 
WHITBECK: Well, with the winds - well, I was going to say the winds had lessened in strength, but we still do get some strong gusts.

1.5 .

MOOS: NBC's Al Roker managed to stay upright.

AL ROKER, NBC METEOROLOGIST: We actually had to climb over trees to get here.

MOOS: At least he didn't have to climb over the guy trying to hold $\mathrm{Al}$ in place back when he covered Hurricane Wilma.

1.6 .

ROKER: Right about now I feel...

(VIDEO OF ROKER FALLING)

UNIDENTIFIED FEMALE: Are you OK?

ROKER: We're OK. We're OK. We're OK.

1.7 .

MOOS: Sometimes it was hard to see if things were OK.

UNIDENTIFIED MALE: No, no, no, no.

MOOS: And even when the sun came up, a single strategically situated drop could obscure a weatherman's head.

UNIDENTIFIED MALE: Your community is well informed...

MOOS: Requiring an ever so subtle pan-over. Our favorite cameo was by this iguana, who kept getting replayed on CNN's storm coverage. We almost mistook him for this guy.

(BEGIN VIDEO CLIP FROM GEICO AD)

UNIDENTIFIED MALE: No one ends up looking foolish.

(END VIDEO CLIP)

MOOS: Insurance isn't such a bad idea for weather-beaten reporters.

ROKER: We're OK. We're coming inside.

MOOS: Jeanne Moos, CNN, New York.

(END VIDEO TAPE) 